CZU:811.135.1'367.612..2:821.135.1-31(478).09

https://doi.org/10.52505/filomod.2021.15.45

\title{
METAFORA „ZBORULUI FRÂNT”
}

\author{
Dan VEREJANU \\ Institutul de Filologie Română „B. P.-Hasdeu” al MEC
}

Rezumat. Vladimir Beșleagă, prozatorul, poetul, traducătorul, unul dintre cei mai remarcabili romancieri basarabeni ai generației dezghețului hrușciovist, model de libertate și omenie, în romanul „Zbor frânt" a oferit eroului liric posibilitatea să reproducă amintirile sale, aceste monologuri sau discursuri cu sine însuşi metafore uimitoare care se constituie dintr-o frază, un alineat destul de mare sau chiar pagini întregi. Autorul a construit o inedită interpretare metaforică a gândului, a dialogului interior. In „Zbor frânt” metaforă nu e doar limbajul cu întreaga plenitudine funcțională, nu doar mijloc de exprimare, ci și de investigație a lumii. Beşleagă „valorizează posibilitățile” metaforei extinse, lumea proprie a omului, starea sufletească interioară, dar și invizibilul, „aşa-zisul metafizic, ceea ce este dincolo", şi constituie suflarea acestei lucrări, „trăirea mesajului ei profund”. In „Zbor frânt” nașterea metaforei e din realul „,plin de posibilităţi”, din exploatarea destinului personajelor lucrării, fie că e vorba de Isai sau de râul Nistru.

Cuvinte-cheie: Metafore extinse, demnitate, universuri, matrice stilistică senină, amplă figură textuală, libertate lăuntrică, dialoguri inerente, monologuri, actualizare, socializare.

Abstract. Vladimir Besleaga, the novelist, poet, translator, one of the most remarkable novelists of Bessarabia from the Hruschev defrosting generation, a model of liberty and humanity, has offered in the novel „Broken fligh" the lyrical hero the chance to reproduce his memories, these monologues - amazing metaphors which are composed of a phrase, a paragraph or even entire pages. The author has built an innovative metaphorical interpretation of the thought, the inside dialogue. In „Broken flight" the metaphor is not only the language with its functional power, not only a way of expressing things, but also an investigation into the world. Besleaga values the possibilities of the extended metaphor, man's own world, inner feelings but also the invisible, so called metaphysical, what is beyond, which constitutes the core of this work, the living of its profound message. In „Broken flight" the metaphor is born out of the realm full of possibilities, from the exploitation of the destiny of the leading characters, whether is Isai or the river Nistru.

Keywords: extended metaphors, dignity, universes, clear stylistic matrix, ample textual figure, inner freedom, inherent dialogues, monologues, update, socialization.

Vladimir Beșleagă, analistul fin, mai mult ca în oricare altă lucrare a sa, e preocupat în Zbor frânt de procesele de conștiință, comunicarea dintre conștient și inconștient fiind folosită pe parcursul întregii lucrări nu ca un 
simplu decor, ci e chiar matricea în care prozatorul își creează motivațiile profunde și convingătoare. Prozatorul însuși simte nevoia urgentă de a reînnoi, în primul rând, atitudinea personajului principal faţă de sine însăși. De unde și libertatea lăuntrică nemaiîntâlnită. $\mathrm{O}$ astfel de libertate de mișcare în timp și spațiu este caracteristică scriitorilor de pe linia întâi a vieții. Vladimir Beșleagă şi-a impus o formulă şi un scris unic. Maturitatea artistică din Zbor frânt scriitorul nu și-o poate lămuri nici azi. S-ar părea că toți exegeții nu mai observă celelalte peste 20 de titluri de cărți ale lui Vladimir Beșleagă, toți s-au focusat pe Zbor frânt. Cu toate acestea, problematica sugerată în această lucrare e insuficient abordată de exegeză. Incercarea noastră de-a vorbi de metafora monologului, dialogului cu sine în Zbor frânt este motivată de lipsa unor studii ample şi sistematice despre metafora prozei generaţiei de aur, despre metaforicitatea limbajului ei.

Romanul lui Vladimir Beșleagă Zbor frânt vede lumina tiparului mai întâi în varianta de revistă, cu titlul din manuscris: „Ţipătul lăstunilor”. La editură, în 1966, scriitorul alege alt nume ,unul concis, dur, dramatic până la... tragic, precum e şi mesajul cărţii”, zise autorul. Lucrarea (originală și ca formă - o întindere de proză fără început și sfârșit, o povestire, o nuvelă de 200 pagini care reprezintă un singur capitol, cu foarte puțin dialog, chiar și cu foarte puține alineate, toată din amintiri, din monologuri, necesită efort la citire) a fost nominalizată la Premiul de Stat al RSSM (1968), dar nu primește premiul în acel an. În prezent romanul a ajuns la ediția a IX.

Metafora monologului, de care suntem preocupați în acest eseu, accentuează și conturează un relief deosebit de cel din literatura moldovenească de până la Zbor frânt, e comunicarea cu cei aflați la același nivel de zbor, mesaj precaut și sigur. Autorul a construit o inedită interpretare metaforică a frazei, a monologului, a dialogului interior, a gândului. În Zbor frânt metafora îndeplinește funcții distincte, scriitorul folosind metafore „uimitoare”, or, anume metafora este ,fantasticul instrument de descoperire a lumii, este o cale de pătrundere spre adevăr”, afirmă Ana Blandiana: „Metafora a adus prozei moderne ceea ce a adus microscopul științei: posibilitatea de a vedea însăși structura elementelor din care este compusă viața... Scriitorii moderni, contemporani subtilelor descoperiri științifice ale secolului nostru, nu au fost, deci, decât sincroni cu epoca atunci când au descoperit că în literatura nu exista adevăr mai exact decât ambiguitatea metaforei", afirmă scriitoarea

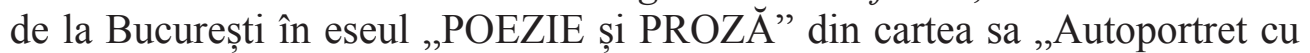
palimpsest" (Blandiana, 2004, p.28).

Scriitorul de la Mălăieștii de pe malul stâng al Nistrului, în Zbor frânt a găsit calea sa „de pătrundere spre adevăr”, de descifrare și descoperire a lumii. Autorul unei proze moderne, prozatorul, privindu-și ades personajul drag, râul (râul Nistru), se întreabă: „Cum să nu fie mâhnit, dacă mare prăpăd și pârjol s-a lăsat asupra lui, și măcar că a pătimit atâtea, dar ca acum nu 
ține minte să fi văzut vreodată. Uneori, când cele două focuri de pe cele două maluri se incleaștă la luptă și se izbesc piept în piept, pe moarte, nu pe viață, și se reped în sus, focurile, apoi cad iar, atunci ia foc și apa lui, apa Nistrului, și începe să ardă și ea. Și arde cu pară, dar nu-i galbenă para, ci-i roșie, că-i sânge, sânge de om... Și sângele acesta se întinde pe trupul lui, al Nistrului, și îl doare, îl frige tare. Îl mână Nistrul repede, sângele acela, la vale și-l duce repede spre mare, ca să se spele de el și să se simtă iar curat cum a fost, dar nu poate: vine altul din urmă, alt sânge, sânge de om... S-ar răzvrăti Nistrul... Ar țipa Nistrul: ce faceți voi, oamenilor?” (Beșleagă, 1998, p.54).

În Zbor frânt râul Nistru, personajul suficient sieși, cu importanță istorică durută după alt război, zis, ,războiul de pe Nistru” (din 1992) va da mister romanului, oferind o notă „de prospețime și candoare, de simplitate binefăcătoare”. În pasajul citat din „Zbor frânt” metaforă nu e doar limbajul cu întreaga plenitudine funcțională, nu doar mijloc de exprimare, ci și de investigație a lumii. Beșleagă „valorizează posibilitățile” metaforei extinse, lumea proprie a omului, starea sufletească interioară, dar și invizibilul, ,așazisul metafizic, ceea ce este dincolo", și constituie suflarea acestei lucrări, „trăirea mesajului ei profund”. În „Zbor frânt” nașterea metaforei e din realul „plin de posibilităț”, din exploatarea destinului personajelor lucrării, fie că e vorba de Isai sau de râul Nistru.

Acad. M. Cimpoi a citit romanul de la bun început atent și a văzut prin intermediul destinului lui Isai o luptă pentru demnitatea şi frumusețea omului: „Eroul romanului subliniază mândria de a fi om. Este în Zbor frânt un patos gorkian cu linii pronunțate: totul e raportat la om întru afirmarea demnităţii şi frumuseţii lui” (Beșleagă, 2011, p. 36). În întreaga creaţie a lui Vladimir Beșleagă totul e raportat la om, prozatorul conștientizând că a te raporta la om e mare responsabilitate. Asumându-și trista realitate în care i-i dat să se mire, Vladimir Beșleagă o face să zâmbească, sau cel puțin să schițeze un zâmbet, să poarte în colțul gurii un surâs care-i va aduce noroc, îl va păzi de fulger, ca un paratrăsnet. Romancierul nu creează realități, ci „universuri și miracole” spre a se îndepărta pe cât e posibil de oamenii cu ghinion, de cei care atrag asupra lor tot răul de pe lume, și, multiplicându-1 îl aruncă pe capul altora.

Metafora, mai ales metaforele extinse, referindu-se la structura conceptuală, rămân a fi o construcție literară, o ,proprietate exclusivă” a autorului și a romanului Zbor frânt. Metaforele celor două maluri ale Nistrului, ale apei care întruna se spală de sânge, ale celui care trece înot de la un mal la altul, deși nimeni nu 1-a văzut cum trece, cum înoată, cum plânge, cum râde... Metaforele unei lupte acerbe a celor două focuri de pe cele două maluri, până „ia foc și apa lui, apa Nistrului”, sunt metafore create de talentul creatorului de destine, creatorului de istorie a unui neam întreg. Pusă în ,relație cu imaginea artistică şi cu simbolul", metafora poate fi considerată rezultatul unui transfer 
de sens. Fără să se epuizeze într-o expresie imediată, metafora din Zbor frânt oferă o amplitudine ce o distinge și-i oferă posibilitatea de a deveni o amplă figură textuală, prin intermediul căreia exegeții și cititorii au posibilitatea de-a pătrunde semnificațiile adânci ale textului romanului.

Înțelegerea metaforelor extinse (mult sau mai puțin) se face dinlăuntrul romanului Zbor frânt, doar astfel vom descoperi adevărurile de la adâncimile acestor metafore, adevărurile promovate de această lucrate, de acest text plin de semnificații. Asumându-și realitatea, și trecând-o iscusit prin tensiunea stării sufletești, avem un roman modern, care poate fi numit prima proză postmodernistă a literaturii basarabene din sec. XX. În Zbor frânt limbajul metaforic se integrează în dinamica semantică a contextului, deoarece în proză, cuvântul „,se dezvoltă”, adică afectează un segment mai vast decât contextul învecinat. Dorind să stabilim sursele ce dau limbajului caracterul său metaforic, vom constata superba comunicare dintre conștient și inconștient, care îi poate susține pe exegeți la decodificarea clară a limbajului metaforic al romanului cu o matrice stilistică senină, transparentă, dar nespus de profundă. Demersul oferit de prozator în romanul Zbor frânt $\hat{i} i$ oferă unicitate, au constatat mai mulți exegeți or, evoluția metaforei, a metonimiei, a parabolei, a alegoriei de la nivelul semantic la cel textual, devine în proza lui Vladimir Beșleagă adevărate figuri textualizante. Uimește și bucură capacitatea scriitorului de-a recrea, prin limbajul metaforic, un conținut nou la acel timp, și atât de actual azi, în mileniul trei. Acest aspect „,pronunțat experimental” nu-l poate lămuri nici autorul romanului scris în doar trei luni, în alte trei luni redactat și editat.

Metafore/monolog, metafore/dialog cu sine în care experiențele personale ale autorului sunt din ce în ce mai mult puse în valoare, (dezvăluind personalitatea modernă o omului Vladimir Beșleagă), nu sunt monotone, ci de o intensă vitalitate, asemeni curgerii râului, până a fi încorsetat în câteva hidrocentrale. La ce i-ar trebui lui Isai să-și amintească toate întâmplările din trecut, pentru ce efortul enorm să-și amintească, să revadă și să treacă prin chinurile prin care a trecut? În subterana acestor monologuri (discuții ale personajului cu subconștientul său, fie dialogul dintre conștient și inconștientul autorului) nu e teama că nu va fi înțeles de propriul fiu, care e „sângelui lui, viaţa lui, suflarea lui”, nu e atât nesiguranța, cât dorința de-a avea un viitor binemeritat. Viitorul său e nemurirea însăși. „De multe ori nu importă subiectul pe care ţi-l alegi, ci propria ta stare sufletească interioară, în care te afli în momentul scrisului”, zice scriitorul într-un interviu. $E$, ,şi ceva care este invizibil, aşa-zisul metafizic, ceea ce este dincolo, ceea ce constituie suflarea acestei cărţi, trăirea mesajului ei profund". În aceste mărturisiri ale prozatorul e multă sinceritate şi dorință ca cititorii să pătrundă acel mesaj profund, să nu se bălăcească la mal cum 
se întâmplă cunoașterea superficială a literaturii prin școlile noaste. Or, „, de unul singur nu poți să faci nimic pe lume, trebuie să cauţi pe ai tăi, cu care să mergi umăr la umăr ", afirmă Vladimir Beșleagă. Zbor frânt „,este mai mult decât un roman-destin", zice autorul.

Această stare sufletească a romancierului e starea sufletească a acestui neam. În monologurile Zborului frânt, în frământările lăuntrice ale personajelor, metafora intensifică, sugerează, marchează, valorifică, înnobilează chiar... Astfel e susținută continuarea atmosferei de înalt, de putere spirituală, de îndemn, de iscusință, de multă curățenie sufletească şi atitudine cavalerească... Te surprinzi în zborul tău pe care-l vrei frumos, senin, la înălțimea pe care o dorești sau pe care o meriți... Lucrarea se distinge prin câteva înălțimi bine determinate: înălţimi ale stărilor sufletești ce atât de firesc predomină narațiunea, dar și monologurile. Să ne imaginăm starea sufletească într-o asemenea clipă, ca cea captată de Vladimir Beșleagă, Poetul, într-o metaforă genială, în aceste versuri ale Domniei sale:

„,...câinele acesta văzând că se apropie haita de lupi cu ochii aprinşi din intuneric porni să scheaune la picioarele mele deodată făcu un salt înainte se intoarse cu botul spre mine şi porni el primul să urle..."

Sunt rânduri atât de asemănătoare cu cele din romanul Zbor frânt. E o stare sufletească anume. Romanul Zbor frânt, ca și poemele sale, abundă de alese stări sufletești, devenite metafore ce colorează dramatic narațiunea, îi oferă profunzime, prospețime și o extindere de interpretări. Poetul Emil Galaicu-Păun, la debutul poetic a lui Vladimir Beșleagă cu volumul de poezii „T,ipătul lăstunului”, se întreba dacă „,nu cumva poezia joacă rolul de camerton”, presupunând că poate fi ,căutarea tonului personal între o probă de orchestră şi o reprezentaţie cu public (romanele sunt nişte concerte simfonice, nu-i aşa?!...), versurile fiind scrise pe durata întregii vieţi de creator".

În romanul Zbor frânt Beșleagă folosește o metaforă „magistrală”, ce deține puterea de-a informa și generațiile care vin, de-a destăinui și explica o mare durere atât a unui om, cât și a unei societăți, care, pe când se credea că a fost furată, umilită, înjosită, aflăm că societatea, lumea totuși nu a fost îndobitocită. Metafora din discursul Zborului frânt are un anume reper, altfel zis, rădăcinile adânci îi sunt zborul și nu deznădejdea acțiunii frânte. Deoarece romancierul nu a „scris cărţi pentru distracţie, pentru plăcere”, ci a „scris din durere”. „Eu scriu când durerea mea este atât de mare, încât eu nu mai pot să rezist”, afirmă scriitorul. Or, ați imagina înseamnă a-ţi aminti ceva din inconștientul tău sau al altor generații, sau chiar a memoriei colective milenare, aducând în prim planul prezentului sau viitorului imediat înfățișări pline de semnificații ale realului de odinioară. Prin acest personaj, să-i zicem, un personaj nostim, pe nume sonor Isai, nume doar cu o singură consoană, restul toate-s vocale, prozatorul basarabean a adus dovada că-i percepe pe fiecare dintre semenii săi ca oameni foarte senini. 
„Proza lui Vladimir Beșleagă, cu formula modern evident proustiană și faulkneriană, valorifică fluxul memoriei, elementul eseistic, interogația polemică", afirmă acad. Mihai Cimpoi în Biobibliografia lui Vladimir Beșleagă (Beșleagă, 2011, p. 85). În unul dintre interviuri din acest an aniversar, Vladimir Beșleagă zice: „La vârsta la care sunt acum, am ajuns cam tot acolo pe unde eram când eram copil. Este aşa un proverb elen: bătrânii, a doua oară copii. Viaţa pe care o trăieşte omul fie la 30, la 50, la 90 de ani, este una, iar memoria vieții este cu totul altceva. Cu cât viaţa omului, a persoanei, a creatorului este mai bogată, mai variată, mai profundă, mai sinceră, mai, mai, mai... cu atât opera lui este mai interesantă. Substanţa cărţ̧ilor, sufletul, inima, esenţa cărţilor, este în tine, în autor." În concluzie, metafora „Zborului frânt” intensifică, sugerează, marchează, valorifică mesajul tragic al lucrării.

\section{Referințe bibliografice:}

1. BEȘLEAGĂ, Vladimir. Zbor frânt. Chișinău, 1998.

2. BLẢNDIANA, ANA. Autoportret cu palimpsest. București, 2004.

3. BEȘLEAGĂ, Vladimir. Omul luminat, Chișinău, 2011. 2011.

4. BEȘLEAGĂ, Vladimir. Bibliografie selectivă. Bibl. B.P. Hașdeu, Chișinău,

Notă: Articolul a fost realizat în cadrul proiectului de cercetare 20.80009.1606.03 Contexte socioculturale autohtone şi interconexiuni europene în creaţia populară şi literatura cultă din Basarabia (sec. XIX până în prezent), Institutul de Filologie Română „B. P.-Hasdeu” al MEC. 